\title{
Fish Bone-Catalyzed Methanolysis of Waste Cooking Oil
}

\author{
Sarina Sulaiman*, M. H. M. Amin \\ Department of Biotechnology Engineering, Faculty of Engineering, International Islamic \\ University of Malaysia, Kuala Lumpur, Malaysia
}

Received: 22 $2^{\text {nd }}$ January 2016; Revised: $2^{\text {nd }}$ February 2016; Accepted: 17th February 2016

\begin{abstract}
The use of cheaper alternative such as waste cooking oil as substitute to vegetable oil can reduce the overall production cost of biodiesel. This research focuses on the investigation of the kinetic of waste cooking oil methanolysis using heterogeneous waste catalyst. Fish bone waste was used as the catalyst for the methanolysis of waste cooking oil. The kinetic data obtained from this study can be used to optimize the process of biodiesel production. The effects of temperature and catalyst amount were varied between $50-65{ }^{\circ} \mathrm{C}$ and $4-10$ wt \% respectively. The kinetic of transesterification of waste oil, the reaction rate constant $(k)$ and activation energy $\left(E_{A}\right)$ at 55,65 and $65{ }^{\circ} \mathrm{C}$ were determined. The highest yield of biodiesel, $86 \%$ were achieved at $6 \mathrm{wt} \%$ of catalyst amount, mixing of $300 \mathrm{rpm}$, methanol to oil ratio of $18: 1$ and reaction temperature of $65{ }^{\circ} \mathrm{C}$. The activation energy $\left(E_{a}\right)$ was $34.12 \mathrm{~kJ} / \mathrm{mol}$. This study also proves that transesterification process is not affected by the internal mass transfer due to the Thiele modulus value between 0-1.69. Copyright ( 2016 BCREC GROUP. All rights reserved
\end{abstract}

Keywords: Fish bone catalyst; Biodiesel; Waste cooking oil; Kinetic

How to Cite: Sulaiman, S., Amin, M.H.M. (2016). Fish Bone-Catalyzed Methanolysis of Waste Cooking Oil. Bulletin of Chemical Reaction Engineering \& Catalysis, 11 (2): 245-249

(doi:10.9767/bcrec.11.2.556.245-249)

Permalink/DOI: http://dx.doi.org/10.9767/bcrec.11.2.556.245-249

\section{Introduction}

Biodiesel has been used as a substitute oil source in replacing the petroleum fuel. Recently, a lot of research have been done in the field of biodiesel and its benefit for heating fuel and off-road fuel for heavy equipment [1]. Sudden increase in the petroleum prices and growing demand of petroleum products induces the search for other renewable energy. Biodiesel is clean, emits lesser greenhouse gases, ecological friendly and reduces the need on imported oil.

* Corresponding Author.

E-mail: sarina@iium.edu.my (S. Sulaiman),

Telp: +60361966550, Fax: +60361964442
The petroleum diesel source is facing scarcity due to non-renewable source. It is reported that the production of biodiesel is expensive and half times higher than that of petroleum diesel [2]. The higher cost is contributed by raw material; which contributes around 70-95 \% of biodiesel price. Therefore, feedstock such as waste cooking oil (WCO) has been utilized as it is available at a cheaper price or free and gives a waste management solution [2,3]. The reaction of waste cooking oil, methanol and sodium hydroxide gives higher percentage yield of biodiesel of $97 \%$. Refined vegetable oil contains less than $0.5 \%$ by weight of FFAs, but waste cooking oil contains between $0.5 \%$ and $15 \%$ by weight of FFAs [4]. Usually production of biodiesel from waste cooking oil through trans- 
esterification or methanolysis requires catalyst such as alkali homogenous catalyst, alkali heterogeneous catalyst, acid homogenous, acid heterogeneous or enzyme [5].

Homogeneous catalysts causes soap thus reducing the catalytic efficiency [6]. This process increases the viscosity and the formation of gels occurs. The method for the removal of the catalyst after transesterification is tedious and a large amount of wastewater is produced. Furthermore, a long settling time is needed for the separation of glycerol and ester phases. Alternatively, heterogeneous catalysts have the general advantage of being reused and easy to separate from the products. Sources of waste such as chicken oyster shell, egg shell, golden apple snail, mud crab shell, meretrix venus and mollusk shell as rich sources of $\mathrm{CaO}$ is cheap and can be utilized as heterogeneous catalyst for production of biodiesel [7]. Our previous study showed that fish bone is suitable to be used as catalyst to produce biodiesel using palm oil [8]. To date there is no study was reported on the kinetic study of waste cooking oil as raw material and fish bone as the heterogeneous catalyst.

Thus this research aims to study the effect temperature and catalyst amount of waste cooking oil catalyzed by waste material; fish bone. The effectiveness of the heterogeneous process depends on several parameters; methanol to oil molar ratio, temperature and amount of catalyst. A kinetic study was also conducted and the reaction rate constant $(k)$ and activation energy $\left(E_{A}\right)$ at 55,65 and $65{ }^{\circ} \mathrm{C}$ were determined.

\section{Materials and Methods}

\subsection{Material}

The waste cooking oil (with free fatty acid of $1.6 \%$ ) and the fish bone was collected from the cafeteria of International Islamic University Malaysia. Methanol (99.6\%) (Analytical grade) and n-hexane (GC analysis) were purchased from MERCK (Malaysia).

\subsection{Catalyst Preparation}

The fish bones were washed with water and were dried. The bones were grinded for $10 \mathrm{~min}$ using a grinder and separated with sieve plates. The bones were mixed with nitric acid for 2 to 3 minutes then rinsed with distilled water. The bones were dried in an oven at $100{ }^{\circ} \mathrm{C}$ for 24 hours. Then the bones were calcined in a furnace for 3.5 hour at $900{ }^{\circ} \mathrm{C}$.

\subsection{Methanolysis}

The extraction process was conducted using batch reactor. Temperature, mixing and heating of the solvent was provided by a hot digital magnetic stirrer. $10 \mathrm{~mL}$ of waste cooking oil was weighted. The catalysts were varied from $4 \%, 6 \%, 8 \%$, and $10 \%$ on the basis of the weight of the oil. The reaction temperature was varied from 55, 60 and $65^{\circ} \mathrm{C}$ and reaction time was varied from 5 minute to 120 minute.

After the reaction, the catalyst was separated from the mixture by vacuum filtration through a filter paper. Then, the mixture was poured into a separating funnel, allowing the biodiesel and glycerol to separate. The upper biodiesel layer is collected. For purification, the biodiesel was washed with warm water (45-50 $\left.{ }^{\circ} \mathrm{C}\right)$ to purify and remove impurities from the oil.

The biodiesel composition was analyzed using GC $7890 \mathrm{~A}$ (Agilent). $0.1 \mathrm{~mL}$ of sample was diluted with $3.9 \mathrm{~mL}$ of $\mathrm{n}$-hexane and $1 \mathrm{~mL}$ of sample was injected into GC. The column was a $60 \mathrm{~m} \times 0.248 \mathrm{~mm} \times 0.15 \mathrm{~mm}$ DB 23 column (J\&W Scientific, USA). The standard mixture of fatty acid (GLC 10 FAME mix) was bought from Sigma Aldrich. Oven temperature was set to $50{ }^{\circ} \mathrm{C}$ for $1 \mathrm{~min}$ before increasing it to $175{ }^{\circ} \mathrm{C}$ at a rate of $4{ }^{\circ} \mathrm{C}$. Then the temperature increased to $235{ }^{\circ} \mathrm{C}$ at a rate of $4{ }^{\circ} \mathrm{C} / \mathrm{min}$ and held for $5 \mathrm{~min}$. The yield of methyl esters was calculated based on fatty acid methyl ester (FAME) using the Equation (1) [9]. The percentage composition of the FAMEs was determined based on the peak area of the individual component relative to the total peak area of all the components present in the sample [10].

$$
\text { FAME Yield }(\%)=\frac{\text { Total FAME }(g)}{\text { Amount of oil used }} \times 100 \%
$$

\subsection{Internal mass transfer within the par- ticle}

The investigation of mass transfer within the catalyst based on the Thiele modulus was carried out to define the transesterification process was not controlled or limited by the internal diffusion [11]. The value of Thiele modulus $(\phi)$ and effective diffusivity $\left(D_{\text {eff }}\right), \mathrm{m}^{2} \mathrm{~s}^{-1}$ was calculated by assuming $D_{\text {eff }}$ is constant with the $Y$, yield at time, $t$ and initial yield of the oil based on Fick's second law. Pinelo, Sineiro et al. $[11,12]$ calculated effective diffusivity using Equation (2). 


$$
\ln Y=\ln \left(\frac{6}{\pi^{2}}\right)-\frac{\pi D_{e f f}}{r^{2}} t
$$

where, $r(\mathrm{~mm})$ is the ratio of particles. By using Equation (2), a plot $\ln Y$ versus time of experiment was plotted. The value of the slope was used to determine the effective diffusivity.

To determine the effect of mass transfer within the catalyst, Thiele Modulus, $\phi$, was calculated based on Giri and Sharma [11, 13] in Equation (3):

$$
\phi=\frac{d_{p}}{6}\left(\frac{K \rho_{p}}{d_{e f f}}\right)^{0.5}
$$

where $d_{p}$ is the particle diameter, $K$ is the extraction rate, $\mathrm{s}^{-1}, r_{p}$ is the density of the coconut waste. The system is expected to have no internal mass transfer limitation if the Thiele Modulus is less than 2, and the system suffers from the internal mass transfer limitation if it is above $10[11,13]$.

\subsection{Kinetic studies}

In biodiesel production, triglycerides are converted to glycerides, then to monoglycerides and to methyl ester. In each step a molecule of methanol is consumed to yield a molecule of methyl ester [14]. The three step mechanisms were simplified to one step as [15-17]:

$$
T G+3 \mathrm{MeOH} \stackrel{k}{\longrightarrow} \mathrm{G}+3 \mathrm{ME}
$$

However with excessive methanol, the reaction was irreversible and this is a first order reaction with respect to the triglycerides concentration. The reaction rate, $r$ was given as:

$$
r=-\frac{d C_{T G}}{d t}=-k C_{T G}
$$

where $C_{T G}$ are triglycerides concentration at any time, $\mathrm{t}$ and beginning $(t=0)$ and after integration. Since $T G$ concentration is related to conversion degree of $T G, x_{A}$ (biodiesel conversion) as follow:

$$
C_{A}=C_{A, 0}\left(1-x_{A}\right)
$$

Then the model could be written as:

$$
\ln (1-x)=-k t
$$

\section{Results and Discussion}

\subsection{Effect of amount of catalyst}

Figure 1 shows the effect of amount of the catalyst on waste cooking oil methanolysis at $55^{\circ} \mathrm{C}$ and molar ratio of $18: 1$. The mixing was remained at $300 \mathrm{rpm}$ for 120 minutes. The yield was at $65.1 \mathrm{wt} \%, 74.7 \mathrm{wt} \%, 68.0 \mathrm{wt} \%$ and $66.5 \mathrm{wt} \%$ for $4,6,8$ and $10 \mathrm{wt} \%$ respectively at 120 minutes. The yield increases gradually by increasing the amount of catalysts at $6 \mathrm{wt} \%$. However beyond 6 wt\%, the yield decreases showing the excess catalyst leads to an increase in viscosity of the mixture [16]. Another researches reported that increase in catalyst concentration at a fixed mixing rate causes diffusion resistance and heterogonous process becomes mass transfer limited. This reduces the conversion of stearic acid [18]. Therefore, it could be concluded that optimum amount of catalyst for this reaction is $6 \mathrm{wt} \%$.

\subsection{Effect of temperature and time}

Figure 2 shows effect of temperature and time on biodiesel yield at 55, 60 and $65^{\circ} \mathrm{C}$. Mixing was remained at $300 \mathrm{rpm}$ and methanol to oil ratio of $18: 1$ for 120 minutes. The figure shows an increase in biodiesel yield after 30 minutes and slows gradually before becoming stable. For $6 \mathrm{wt} \%$ of catalyst amount and at 60 ${ }^{\circ} \mathrm{C}$ the yield was $79.3 \mathrm{wt} \%$ at 30 minutes, 79.9 $\mathrm{wt} \%$ at 60 minutes and $79.6 \mathrm{wt} \%$ at $120 \mathrm{~min}-$ utes. Increase in temperature and time increases the biodiesel yield and a maximum

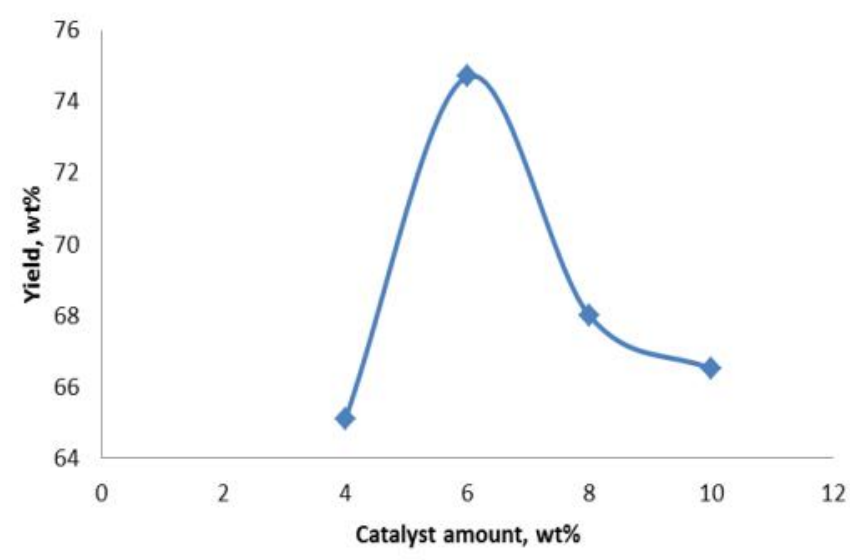

Figure 1. Effect of amount of catalyst on biodiesel yield at $50{ }^{\circ} \mathrm{C}$ 
yield of $86 \mathrm{wt} \%$ was achieved at $65{ }^{\circ} \mathrm{C}$ after 2 hour. This results are comparable with other studies that higher temperature favors the biodiesel yield $[16,19]$. When the reaction was conducted exceeding the boiling point of methanol at $65{ }^{\circ} \mathrm{C}$, the solvent vaporized and remained in the vapor phase in the reactor causing a reduction in the methanol in the reaction media [16] .

\subsection{Internal mass transfer within the par- ticle}

Based on the calculation using Equations (2) and (3), the Thiele modulus is $1.69,0.89$ and 0 for 50, 60 and $65{ }^{\circ} \mathrm{C}$ respectively. This proves that transesterification process is not affected by the internal mass transfer due to the Thiele modulus value which is less than 2. Small value of Thiele modulus indicates that the reaction was surface reaction limited and decreases the internal mass transfer diffusion limitation [11].

\subsection{Kinetic of methanolysis of waste cook- ing oil}

In this study, the kinetics of transesterification reaction of waste cooking oil using fish bone catalyst $(6 \mathrm{wt} \%)$ at the temperatures of 328, 333 and $338 \mathrm{~K}$ were investigated. The reaction was defined as a pseudo homogeneous reaction according to the kinetic model and the kinetic parameters with fish bone catalysts were determined. Based on the study, the optimum conditions are achieved at stirring speed of $300 \mathrm{rpm}$ and methanol to oil ratio of 18:1. A linear relationship was achieved by plotting the data between $-\ln \left(1-X_{M E}\right)$ and $t$. The experiments demonstrate that the reactions follow first order kinetics.
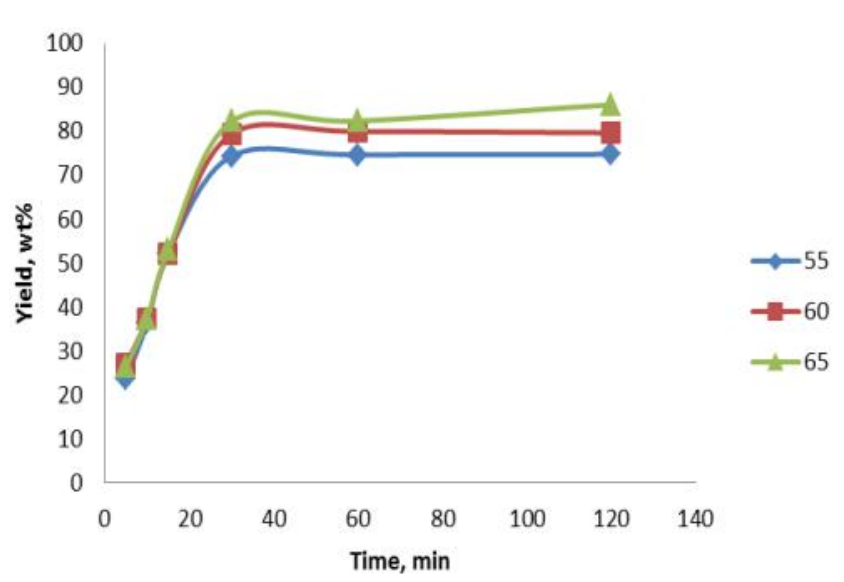

Figure 2. Effect of temperature and time on biodiesel yield
Figure 3 illustrates the plot of -ln $\left(1-X_{M E}\right)$ versus time at different temperatures at methanol to oil molar ratio of $18: 1$, mixing at $300 \mathrm{rpm}$ and amount of catalyst of $6 \mathrm{wt} \%$. The value of reaction rate constant $k$ was determined at different temperature by using Figure 3. Arrhenius Equation was used to calculate the activation energy of transesterification reaction. The slope and intercept between $\ln k$ and $1 / T$ give the values of activation energy $\left(E_{a}\right)$ and frequency factor $(A)$ respectively.

For the transesterification reaction using fish bone, the activation energy $\left(E_{a}\right)$ was 34.12 $\mathrm{kJ} / \mathrm{mol}$. The activation energy for the transesterification of waste cooking oil was in the range obtained by other researchers; 33.6-84 $\mathrm{kJ} / \mathrm{mol}[16,20]$. The $E_{a}$ shows an energy required for the transesterification of WCO that is favorable for biodiesel production. The lower activation energy creates a faster reaction and therefore, it could be concluded that fish bone catalyst would be more efficient for transesterification reaction.

\section{Conclusions}

It can be concluded that the optimum conditions were achieved at $86 \%$ by using fish bone catalyst at $6 \mathrm{wt} \%$, mixing of $300 \mathrm{rpm}$, methanol to oil ratio of $18: 1$ and reaction temperature of $65{ }^{\circ} \mathrm{C}$ for $120 \mathrm{~min}$. The experiments demonstrate that the reactions follow first order kinetics. The activation energy $\left(E_{a}\right)$ and the Thiele modulus were $34.12 \mathrm{~kJ} / \mathrm{mol}$ and $0-1.69$, respectively.

\section{Acknowledgment}

This research is funded by FRGS grant (FRGS 13-079-0320) from Government of Malaysia.

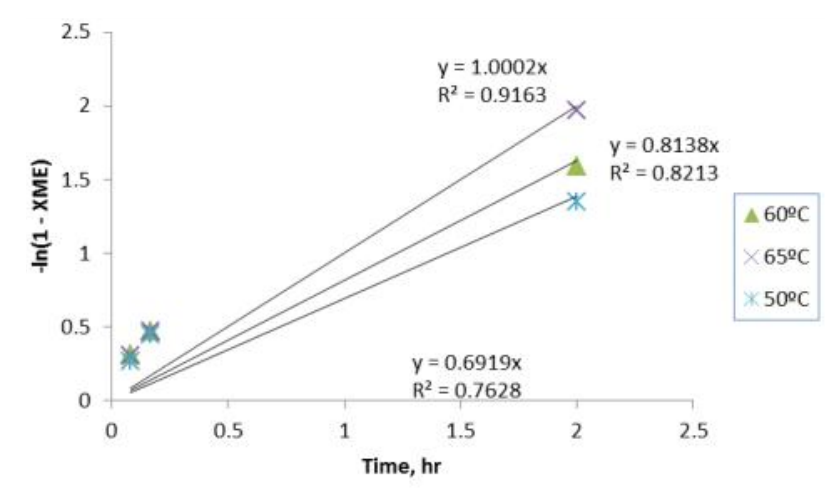

Figure 3. - $\ln \left(1-X_{M E}\right)$ versus time plot at different temperatures at methanol to oil molar ratio of $18: 1$, mixing at $300 \mathrm{rpm}$ and amount of catalyst of $6 \mathrm{wt} \%$ 


\section{References}

[1] Wilson, A. (2003). Biodiesel : A Cleaner, Greener Fuel for the 21 ${ }^{\text {st }}$ Century, in: Environmental Building News, A Publication of Building Green Inc., North American.

[2] Ullah, Z., Bustam, M.A., Man, Z. (2015). Biodiesel production from waste cooking oil by acidic ionic liquid as a catalyst. Renewable Energy, 77: 521-526.

[3] Elkady, M.F., Zaatout, A., Balbaa, O. (2015). Production of Biodiesel from Waste Vegetable Oil via KM Micromixer. Journal of Chemistry, 2015: 1-9

[4] Medina-Valtierra, J., Ramirez-Ortiz, J. (2013). Biodiesel production from waste frying oil in sub- and supercritical methanol on a zeolite Y solid acid catalyst. Frontiers of Chemical Science and Engineering, 7: 401407.

[5] Ehsan, M., Chowdhury, M.T.H. (2015). Production of Biodiesel Using Alkaline Based Catalysts From Waste Cooking Oil: A Case Study. Procedia Engineering, 105: 638-645.

[6] Romero, R., Natividad, R., Martínez, S.L., Biodiesel production by using heterogeneous catalysts, INTECH Open Access Publisher, 2011.

[7] Jazie, A., Pramanik, H., Sinha, A.S.K. (2013). Egg Shell as Eco-friendly Catalyst for Transesterification of Rapeseed Oil: Optimization for Biodiesel Production. International Journal of Sustainable Development and Green Economics. 2(1): 27-32.

[8] Sulaiman, S., Khairudin, N., Jamal, P., Alam, M. Z., Zainudin, Z., \& Azmi, S. (2014). Characterization of fish bone catalyst for biodiesel production. World Academy of Science, Engineering and Technology, International Journal of Biological, Biomolecular, Agricultural, Food and Biotechnological Engineering, 8(5): 476-478

[9] Rashid, U., Anwar, F., Jamil, A., Bhatti, H.N. (2010). Jatropha curcas seed oil as a viable source for biodiesel. Pakistan Journal of Botany, 42: 575-582.

[10] Abdulkadir, S., Tsuchiya, M. (2008). One-step method for quantitative and qualitative analysis of fatty acids in marine animal samples. Journal of Experimental Marine Biology and Ecology, 354: 1-8.
[11] Sulaiman, S., Abdul Aziz, A.R., Kheireddine Aroua, M. (2013). Optimization and modeling of extraction of solid coconut waste oil. Journal of Food Engineering, 114: 228-234.

[12] Pinelo, M., Sineiro, J., Núñez, M.J. (2006). Mass transfer during continuous solid-liquid extraction of antioxidants from grape byproducts. Journal of Food Engineering, 77: 57-63.

[13] Giri, C.C., Sharma, D.K. (2000). Masstransfer studies of solvent extraction of coals in N-methyl-2-pyrrolidone. Fuel, 79: 577-585.

[14] Permsuwan, A., Tippayawong, N., Kiatsiriroat, T., Thararux, C., Wangkarn, S. (2011). Reaction Kinetics of Transesterification Between Palm Oil and Methanol under Subcritical Conditions. Energy Science and Technology, 2: 35-42.

[15] Sulaiman, S., Abdul Aziz, A.R., Aroua, M.K., Optimization and Modeling of Extraction of Solid Coconut Waste Oil. Journal of Food Engineering. 114(2): 228-234

[16] Birla, A., Singh, B., Upadhyay, S., Sharma, Y. (2012). Kinetics studies of synthesis of biodiesel from waste frying oil using a heterogeneous catalyst derived from snail shell. Bioresource Technology, 106: 95-100.

[17] Lukić, I., Kesić, Ž., Skala, D. (2014). Kinetics of Heterogeneous Biodiesel Synthesis Using Supported $\mathrm{ZnO}$ as Catalyst. Chemical Engineering \& Technology, 37: 1879-1884.

[18] Naskar, M. (2012). Studies of Reaction Kinetics in Biodiesel Synthesis. Doctoral Dissertation, Jadavpur University.

[19] Wei, Z., Xu, C., Li, B. (2009). Application of waste eggshell as low-cost solid catalyst for biodiesel production. Bioresource Technology, 100: 2883-2885.

[20] Moradi, G., Mohadesi, M., Ghanbari, M., Moradi, M., Hosseini, S., Davoodbeygi, Y. (2015). Kinetic comparison of two basic heterogenous catalysts obtained from sustainable resources for transesterification of waste cooking oil. Biofuel Research Journal, 2: 236-241.

Selected and Revised Papers from The International Conference on Fluids and Chemical Engineering (FluidsChE 2015) (http://fluidsche.ump.edu.my/index.php/en/) (Malaysia, 25-27 November 2015) after Peer-reviewed by Scientific Committee of FluidsChE 2015 and Reviewers of BCREC 